\title{
Lusioersily
}

\section{Gender differences using online auctions within a generation $Y$ sample: An application of the Theory of Planned Behaviour}

McLaughlin, C., Bradley, L., Prentice, G., Verner, E-J., \& LOANE, S. (2020). Gender differences using online auctions within a generation $Y$ sample: An application of the Theory of Planned Behaviour. Journal of Retailing and Consumer Services, 56, 1-13. [102181]. https://doi.org/10.1016/j.jretconser.2020.102181

Link to publication record in Ulster University Research Portal

Published in:

Journal of Retailing and Consumer Services

Publication Status:

Published (in print/issue): 01/09/2020

DOI:

10.1016/j.jretconser.2020.102181

\section{Document Version}

Publisher's PDF, also known as Version of record

\section{General rights}

Copyright for the publications made accessible via Ulster University's Research Portal is retained by the author(s) and / or other copyright owners and it is a condition of accessing these publications that users recognise and abide by the legal requirements associated with these rights.

\section{Take down policy}

The Research Portal is Ulster University's institutional repository that provides access to Ulster's research outputs. Every effort has been made to ensure that content in the Research Portal does not infringe any person's rights, or applicable UK laws. If you discover content in the Research Portal that you believe breaches copyright or violates any law, please contact pure-support@ulster.ac.uk. 


\title{
Gender differences using online auctions within a generation Y sample: An application of the Theory of Planned Behaviour
}

\author{
Christopher McLaughlin ${ }^{a, *}$, Laura Bradley McCauley ${ }^{\mathrm{b}}$, Garry Prentice ${ }^{\mathrm{c}}$, Emma-Jayne Verner ${ }^{\mathrm{c}}$, \\ Sharon Loane ${ }^{\text {b }}$ \\ a Department of Business, Institute of Technology Sligo, Ash Lane, Sligo, Ireland \\ b Department of Global Business and Enterprise, Ulster University Business School, Ulster University, Northland Road, Londonderry, BT48 7JL, UK \\ ${ }^{\mathrm{c}}$ School of Arts, Dublin Business School, 13/14 Aungier, Dublin 2, Ireland
}

\section{Introduction}

Online auction sites have evolved as one of the main alternative consumer channels (Pinker et al., 2003 \& 2010), with the global online auction market predicted to grow by 7.2 per cent ( $\$ 1.05$ billion) between 2018 and 2022 (Business Wire, 2018). This, in turn, is redefining consumer shopping (Mohamed et al., 2014). eBay, as one of the most popular online auction services, accounts for billions of dollars' worth of transactions a year (eBay Inc, 2019), and there is an ever-increasing number of customer engagements with the service (Roggio, 2012; Garbarino and Strahilevitz, 2004; Ow et al., 2018). With this increase in the use of online auctions, there is an even greater need to understand the key drivers of users' decisions and behaviours in relation to such services (Pavlou and Fygenson, 2006; Drake et al., 2012; Mohamed et al., 2014). Hou and Elliott (2016), in fact, suggest that online auctions have specific nuances when compared to online shopping generally and that this requires specific investigation in terms of differences in volumes of buyers, processes and time engagement. It is therefore reasonable to assume that online auction participants' behaviour and influences may be very different from those of other online shoppers (Hou and Elliott, 2010). This presents a further compelling reason to explore online auctions specifically, as outlined in this paper.

Specifically, this paper will attempt to provide a greater understanding of how online auction consumers' behave and what are the key factors likely to influence and predict their behaviour, thereby extending existing consumer behaviour theory and, on a practical level, providing online auction sites such as eBay with a better understanding of the nuances of the consumer ecosystem so as to better inform marketing decisions and choices. The research therefore aims to apply the Theory of Planned Behaviour (TPB) model (Ajzen, 1991) to assist with predicting individuals online auction decisions and usage. Furthermore, the TPB model will be extended firstly by splitting the perceived behavioural control (PBC) construct into self-efficacy and perceived control, and secondly by including both trust and security within the framework. Though some research has applied the TPB to predict other e-commerce behaviours, little research has explored online acutions like this before. Also, this research will include two additional factors of interest which have not been applied previously around predicting online auction usage with the TPB; namely Generation Y individuals who are one of the most online engaged groups and gender. Both groups are seen as important factors to better understand online auction usuage on platoforms such as eBay. Despite the potential impact of generation and gender on decision making, this has not been intergrated into a TPB study as it outlined within study - further supporting the value and contribution of the research outlined in this paper.

To conclude, this research aims to provide better understanding of male and female descion making around using online acutions like eBay at a time when more and more indiviuals are engaging with such services. From an academic point of view this helps understand possible differences in the psychological and behaviour process around online auctions by gender and age demographics. Also, for companines who benefit from knowing what impacts on the decisions of their users, especially around gender and the Gen Y population, this research will inform their marketing and commercial strategies.

\section{Background literature}

The customer-to-customer (C2C) online auction is a form of e-commerce that has become increasing popular over recent years (McLaughlin et al., 2017). This popularity has been due to several

\footnotetext{
* Corresponding author.

E-mail addresses: mclaughlin.christopher@itsligo.ie (C. McLaughlin), lm.bradley@ulster.ac.uk (L.B. McCauley), Garry.Prentice@dbs.ie (G. Prentice), emmajayneverner@gmail.com (E.-J. Verner), sp.loane@ulster.ac.uk (S. Loane).
} 
important factors such as users' perceptions of its convenience (Verhagen and Dolen, 2011; Majadi et al., 2018), competitive pricing (Zhou et al., 2007) and ease of locating products and services (Weinberg and Davis, 2005) among others. Interestingly, some users view the enjoyment and experience of the bidding process as another important motivation (Rauniar et al., 2009). Irrespective of whether an individual has a particular preference for an online auction site, like eBay, there is no doubt that there is an increasing number of individuals joining various online auction sites and that their behaviour requires further investigation, especially around the motivations of individuals to engage or not engage (McLaughlin et al., 2017). It is important to understand that the changing motivations of these $\mathrm{C} 2 \mathrm{C}$ online auction users are in turn changing the traditional concept of the customer. More specifically, the customer is no longer just buying a product but also selling a product too (Clausen et al., 2010; McLaughlin et al., 2017). Thus, customers of online $\mathrm{C} 2 \mathrm{C}$ auctions can engage in both buying and selling transactions at the same time and engage repeatedly. The changing nature of the $\mathrm{C} 2 \mathrm{C}$ customer vis-a-vis online auctions, transmuting from traditional customer to buyer-seller, has added to the need for further research (Saputra et al., 2012).

\subsection{Motivations of online auction use}

Schlaegel (2015) specifically supports the application of theoretical frameworks such as Ajzen's (1991) Theory of Planned Behaviour when examining factors influencing consumers' use of online auction marketplaces. In fact, Wells (2014) and McLaughlin et al. (2017) have both echoed this call for future behavioural research to employ conceptual framework models. Similarly, Hou and Elliott (2016) suggest that, since online auctions have specific nuances in comparison to online shopping generally. These nuances relate to the often-large number of buyers for only one item in an auction setting, with pricing often set by a bidding process. It is therefore reasonable to assume that online auction participants' behaviour and influences may be very different from other online shoppers (Hou and Elliott, 2010). Owing to the economic importance of online auctions, there is a need to understand why shoppers or sellers engage with such online platforms (Schlaegel, 2015). Key drivers such as attitudes, subjective-norm (social influence) and control have all been suggested as having an important role to play regarding online transaction behaviour, but it has also been recognised that further research in this area is needed (Drake et al., 2012). Other competing models, such as Multi-Attribute Decision-Making (MADM), have been applied to understand consumer decision making, though from a consumer product or brand choice perspective (Ajzen, 2015). Since these models focus more on consumer choice, they fail to take into consideration the underlying key drivers or motivations to purchase (Ajzen, 2015).

\subsection{The Theory of Planned Behaviour (TPB)}

Decisions or behavioural intentions are central to the TPB model reflecting as it does the motivations necessary to engage with a behaviour: thus the stronger one's decisions, the more likely an individual is to engage with that behaviour (Ajzen, 1991). The three main determinants of intentions in the TBB model are as follows:

- attitudes - these measure individual's positive or negative feelings towards the behaviour

- the subjective-norm (SN) - this reflects the level of perceived social pressure to engage with the behaviour

- the perceived behavioural control (PBC) - this examines the individual's difficulty or ease with carrying out the behaviour.

PBC is the only one of the three determinants to influence behaviour indirectly (through intention) as well as directly (Ajzen, 1991). Research evidence suggests that the PBC construct is indicated by two distinct factors - self-efficacy and perceived control (Terry \& O'Leary, 1995;
Conner and Armitage, 1998). Self-efficacy reflects the individual's level of internal control or ability, while perceived control indicates the individual's ability to overcome external obstacles or barriers (Terry \& O'Leary, 1995; Conner and Armitage, 1998). Previously, the utility of the TPB model (Ajzen, 1991) has been successfully applied to understanding customers' online e-commerce transactions (Pavlou and Fygenson, 2006; Huang et al., 2011; McLaughlin et al., 2017), internet banking (Yousafzai et al., 2010), online gaming (Lee, 2009), business start-up intentions (Kautonen et al., 2015), online safety behaviour (Burns and Roberts, 2013) and general online auction usage (McLaughlin et al., 2017). However, little research has applied TPB (Ajzen, 1991) to predicting online auction engagement.

\subsection{Utility of the TPB}

The utility of the TPB is recognised and acknowledged with potential in many areas. Authors including Schlaegel (2015) have called for the application of TPB to predict consumer's use of online auctions particulary in light of inconsistencies in past evidence; especially regarding which drivers explain individual engagement. For example, Pavlou and Fygenson (2006) and Huang et al. (2011) in their research concluded that participant's attitudes towards online purchasing and PBC had a significant impact on predicting e-commerce intentions. Furthermore, both intentions to purchase and PBC significantly predicted e-commerce behaviours. However, SN failed to have a significant impact. However, the role of SN has not been shown to be as consistent a driver of consumer engagement with online auction, although alternative theoretical models have indicated the significance of SN as a driver (Pahnil, Siponen and Zheng, 2011; McLaughlin et al., 2017). Interestingly, they extended the TPB model (Pavlou and Fygenson, 2006) to include both self-efficacy and controllability as underlying factors of PBC, rather than intentions or behaviour (Conner and Armitage, 1998; McLaughlin et al., 2017). Overall, the findings of these studies indicate the important role of attitudes and PBC as drivers of online auction transactions among consumers. In fact this was further supported by Pavlou and Fygenson (2006) who concluded that TPB (Ajzen, 1991) should be utilised in future e-commerce research.

Previous applications of the TPB have supported its utility to aid in our understanding of consumers' e-commerce usage specifically the traditional model of the TPB has been applied and the key components of attitudes, SN, PBC, intention and behaviour. However, other authors such as Chandra (2015) have recommended that the application of the TPB should be extended further to include additional drivers in order to capitalise more fully on its explanatory powers. Furthermore, the author endorses the benefits of further extending the TPB so 'to predict a great range of behaviours across different populations', (p. 142). Ajzen (2015), the founding father of the model, accepts that the model itself does not fully explain all variations of behaviour, regarding such factors as gender. He himself contends that its wider application and inclusion of additional drivers will only help to further its usefulness.

The current study therefore has employed an extended TPB model with the inclusion of additional drivers. This paper addresses by call by authors such as Pavlou and Fygenson (2006), Drake et al. (2012), Mohamed et al. (2014) and Hou and Elliott (2016), regarding the nuances of online auction sites, the changing consumer behaviour from traditional and, more typical, online retail environments to auctions and the growth in buying/selling behaviour by personal consumers, which now requires the investigation as outlined in this study. We can no longer assume that the influences on consumer behaviour of trust, security and gender, for example, and the resultant impact on behaviours and intentions are fully understood - the landscape has changed in terms of retail and online auction sites which requires investigation of these issues in a contemporary setting. In fact, as is argued by Peighambari et al. (2016) with technology, the economy and society evolving consumer behaviour needs and the influences on this need to be continually explored and examined. 


\subsection{Trust, security and TPB}

The additional drivers of trust and security have also demonstrated an impact on e-commerce transactions. Regarding customers' trust in online auctions, evidence suggests that the lower the perceptions of risk the more likely the customer will engage with the online transaction (Pavlou and Gefen, 2005; Zhou et al., 2007; Shareef et al., 2013; Hou and Elliott, 2016). However, further research is needed, more specifically regarding C2C online auctions (Leonard, 2012; McLaughlin et al., 2017), since most research has focused on the business-to-consumer (B2C) service. Likewise, customers' perception around storage of personal information and security is also an important factor which may impact on e-commerce transaction decisions (Abedelghaffer and Moustafa, 2013; Sanayei and Bahmani, 2012). In fact, Chandra (2015) presented arguments that security and trust both influence e-auction adoption. Hence, both these drivers will be included in the proposed theoretical model. Using this extended TPB model would further understanding of customers' engagement with $\mathrm{C} 2 \mathrm{C}$ online auctions and provide enhanced knowledge of the theoretical underpinnings of online auction use. This could have implications for the preferred marketing strategy used by a service provider to gain a better understanding of behavioural and social triggers (Black, 2007; Harris et al., 2009) of customers.

\subsection{Gender differences and online auctions}

The issue of gender has long been recognised in consumer behaviour as influencing consumer decisions, processes and choices, and is generally considered 'a significant predictor of consumer behaviour' (Rodgers and Harris, 2003; Dittmar et al., 2004; Carpenter and Moore, 2006; Noble et al., 2009; Croson and Gneezy, 2009; Huang and Yang, 2010; Baker and Wakefield, 2012; Hou and Elliott, 2016). Gender has been explored in the context of e-commerce, especially with regard to its role in IT acceptance (Bae and Lee, 2011; Fan and Miao, 2012; Nirmala and Dewi, 2011). It has also surfaced in studies investigating online auctions: Hou and Elliott (2010) looked at online auction participation and gender, and Korgaonkar et al. (2014) explored gender and product preferences. Various studies have drawn multiple conclusions with regard to how males and females behave differently respecting online shopping such as Ruane and Wallace (2013), Yeh et al. (2012), and Sangran et al. (2009). Furthermore, Zhou et al. (2014) suggest that the genders behave differently in terms of needs and decisions. For example, preferences in terms of online services and satisfaction with their perceived utility are clearly impacted upon by gender (Garbarino and Strahilevitz, 2004). Key differences in terms of loyalty and trust have also been attributed to gender (Morgan and Hunt, 1994). Moreover, Kim et al. (2007) concluded that females are slower at making online purchase decisions due to their need for larger volumes of information than their male counterparts. This may be due to the suggestion that females are less trusting than their male peers and have higher levels of perceived risk (Garbarino and Strahilevitz, 2004; Croson and Gneezy, 2009).

Interestingly, however, Lian and Yen (2014) conclude that gender has no impact on e-commerce. Similarly Garbarino and Strahilevitz (2004) argue that the issue is no longer about the numbers of males or females that are engage with e-commerce but rather how they differ using the service. Despite the flurry of activity, in the context of online auctions, Hou and Elliott (2016) conclude that 'little is known about gender differences in online auctions' (p. 123). Generally, online auction behaviour is explained, according to Schlaegel (2015), by trust and experience while ongoing behaviour is explained by risk and experience. This would suggest that online auctions are more complex than other typical online shopping environments. Schlaegel (2015) concluded though without considering the impact of gender - that perceived behavioural controls and subjective norms impact upon consumer intentions within an online auction environment; these pillars are key within the TPB.

Hou and Elliott (2010) suggest that females engage with more online auctions and participate more actively (buying items) than their male counterparts. Generally, it is suggested that, online, females tend to be more risk aware (Garbarino and Strahilevitz, 2004). By contrast, Black (2007) found no significant gender differences in risk awareness, regardless if they were eBay. Hou and Elliott (2016) conclude that gender has no impact upon trust in online bidding activity even if it does impact in terms of types of product purchased. Other findings have indicated that females are more favourable in their attitudes towards eBay (Riedl et al., 2010). Yet another divergent perspective has been opened up by Vicente (2015), who proposes that females, regardless of other demographic characteristics such as age, education and professional status, are less likely to engage in online auction shopping in comparison to male counterparts. Furthermore, consumer demographics such as age are suggested to impact on online shopping behaviour; a longitudinally perspective regarding theses divergences over time could also be explained by the changing state of the economy and consumer confidence.

The lack of consensus of opinion and divergent perspectives further support the need for the current investigation and responds to calls for detailed investigation of individual consumer differences (Zhou et al., 2014; Meyers-Levy and Loken, 2015). Hasan (2010) suggested that investigations of attitudes in online shopping generally are 'scarce' and 'inconsistent' and that therefore, in the context of gender, it 'deserves more attention and better understanding' (p. 597).

\section{Gender differences and online auction motivations: applying the TPB}

Based on the previous literature, the following section of the paper will focus on examining differences in online auction users' attitudes, $\mathrm{SN}, \mathrm{PBC}$, trust and security by their gender. In other words, the following section will follow closely the outline of the TPB (Ajzen, 1991, 2015), exploring each of its main constructs in turn in terms of gender differences. Additionally, each of the sections will formulate hypotheses.

\subsection{Gender differences in attitudes towards online auctions}

Studies have shown that the increase in popularity of online auctions has been due to several important factors such as users' attitudes towards its convenience (Verhagen and Dolen, 2011), competitive pricing (Zhou et al., 2007), and ease of locating products and services (Weinberg and Davis, 2005), among others. As Ajzen (1991) suggests, the more favourable the attitude towards a target behaviour, the greater the likelihood of engagement with that behaviour. Interestingly, some users' attitudes respecting the experience of the bidding process - in terms of enjoyment and so forth - seem to be another important motivation (Hou and Elliott, 2016). Furthermore, the limited research exploring gender differences has led Hou and Elliott (2016) to suggest that little is known about the impact of gender on online auction engagement. What research has been conducted reports that female users have generally more favourable attitudes towards engagement with online auctions such as eBay (Riedl et al., 2010) and specifically towards the availability of bargains, value of products, information about items, and enjoyment of such (Hou and Elliott, 2016).

H1. Favourable attitudes towards online auctions will (a) significantly predict greater intentions to engage with online auction sites, with (b) the female sample reporting a stronger positive link between the variables.

\subsection{Gender differences in $S N$ regarding online auctions}

According to Ajzen (1991), SN is the amount of pressure the individual feels either to engage or not engage with the intended behaviour. Previous research has explored the importance of social motivations and 
its impact on customer decision making (Hou and Elliott, 2016; Li et al., 2017). As Hou and Elliott (2016) suggest, the online shopping experience can be enhanced by social pressures of other shoppers, friends and family members. Thus, the customer shopping experience or can be influenced by salient others, so the shopping process online may not be an isolating experience ( $\mathrm{Li}$ et al., 2017). For example, favourable experiences with others on the website can favourably impact on users' perceptions of the website itself. In summary, the more favourable the $\mathrm{SN}$, the more likely the customer will engage with the online purchasing process (Parsons, 2002; Rohm and Swaminathan, 2004). However, little research exists regarding possible gender differences vis-a-vis the role of SN. Some research suggests that females are more likely to be socially active and less technically oriented than males (Swaminathan et al., 1999; Black, 2007). In contrast to this, Hou and Elliott (2010) suggest that females engage with more online auctions and participate more actively (e.g. purchasing fixed priced offerings) than their male counterparts. Based on these findings, coupled with the need for further research in this area, the following hypotheses are examined in the current study:

H2. Favourable social influences will (a) significantly predict greater intentions to engage with online auction sites, with (b) the female sample reporting a stronger positive link between the variables.

\subsection{Gender differences regarding $P B C$ and online auctions}

Past research has valued the role of PBC in predicting customer's decision making using online auctions (Huang et al., 2011). This supports the notion that customers who feel more in control or confident using online auctions are more likely to engage with them (Bosnjak et al., 2006; Huang et al., 2011). However, consistent with the recommendations of Chen et al. (2007), this research aims to examine the role of customers' self-efficacy and capabilities using online auctions. As mentioned earlier, research evidence suggests that the PBC construct is indicated by two distinct factors, self-efficacy and perceived control (Terry \& O'Leary, 1995; Conner and Armitage, 1998). Self-efficacy reflects the individual's level of internal control or ability, while perceived control indicates the individual's ability to overcome external obstacles or barriers (Terry \& O'Leary, 1995; Conner and Armitage, 1998). Within this research it is important to examine this conceptual distinction, especially in relation to gender differences.

Interestingly, Shehryar (2008) reported that females were more likely to be averse to taking risks regarding bidding and 'time remaining' in online auctions compared to males. In contrast, other research suggests that males' approach to online auctions and e-commerce transactions is more planned (Yeh et al., 2012; Hou and Elliott, 2016), confident (Stafford et al., 2004) and purchase oriented (Carroll, 2008; Lai et al., 2008), while suggest, by contrast, that gender has little or no influence on online auction behaviour. Despite this contradictory evidence, there is an argument for gender-informed research (Hasan, 2010; Hou and Elliott, 2016) for marketing practice, segmentation and product positioning. Therefore, as well as understanding gender differences' impact on online auctions transactions, it is also important to understand the impact of key drivers on customer decision-making (Hou and Elliott, 2016).

H3. Higher levels of (a) self-efficacy and (b) perceived control will significantly predict more favourable intentions to use online auctions

H4. Higher levels of (a) self-efficacy and (b) perceived control will significantly predict greater use of online auction sites

H5. Male sample self-efficacy will have a stronger positive link with using online auction sites compared to the female sample

H6. Male sample perceived control will have a stronger positive link with using online auction sites compared to the female sample

\subsection{Gender differences regarding intentions to use online auctions}

Past research has often focused solely on understanding the role of antecedents (attitudes, SN and PBC) of intentions (Huang et al., 2011) rather than the influence of online auction usage intentions on individuals' online engagement. This does not take away from the need to understand the role of key antecedents of online auction behaviour (Schlaegel, 2015). However, applying the TPB can provide insights into the role of key motivations and their impact not only but also the factors that influence intentions to use online auctions and actual usage. Research would suggest that males use online auction sites such as eBay more than females (Hou and Elliott, 2016), but evidence is still lacking around how motivations differ between males and females using online auctions. While Ajzen (2015) acknowledges that the model does not fully explain all variations in behaviour, including those based on gender, applying this model to online auction usage may enrich our insights in this area.

H7. Favourable intentions to engage with online auctions (a) will significantly predict greater use of online auction sites, with (b) the male sample reporting a stronger positive link between the variables

\subsection{Gender difference in trust and security regarding online auction engagement}

Key differences in terms of loyalty and trust have also been attributed to gender (Morgan and Hunt, 1994). Moreover, Kim et al. (2007) concluded that females are slower at making online purchase decisions due to the need for larger volumes of information than their male counterparts. This may be due to the suggestion that females are less trustworthy than their male counterparts and have higher levels of perceived risk (Garbarino and Strahilevitz, 2004; Croson and Gneezy, 2009). However, further research is needed, more specifically regarding C2C online auctions (Leonard, 2012; McLaughlin et al., 2017), since most research has focused on the B2C service. Likewise, customers' perception around storage of personal information and security is also an important factor, which may influence e-commerce transaction decisions (Sanayei and Bahmani, 2012; Abedelghaffer and Moustafa, 2013). In fact, Chandra (2015) presented arguments that security and trust influence e-auction adoption. Since male and female customers' perceptions of both security and trust are important drivers of online transactions, both these drivers will be included in the proposed theoretical model (see Fig. 1 for proposed theretical model with associated hypotheses).

H8. Favourable ratings of (a) trust and (b) security towards online auctions will significantly predict greater intentions of use online auction sites

H9. Favourable ratings of (a) trust towards online auctions will significantly predict greater online auction sites usage, with (b) the male sample reporting a stronger positive link between the variable

H10. Favourable ratings of (a) security towards online auctions will significantly predict greater online auction sites usage, with (b) the male sample reporting a stronger positive link between the variables

\subsection{Importance of generation $Y$ as a sample group}

Generation Y (Gen Y) was chosen as the focus for the present study because this particular group of consumers - usually defined as those born between 1980 and 1995 - are most likely to be 'digital natives' and therefore more predisposed to online auction activity (Bolton et al., 2013; Lyons, 2016). In fact, Noble et al. (2009) indicate that, as a cohort, Gen $Y$ is highly influential within the market, accounting for 13.8 million people in the UK alone, yet little is understood about their motivations as consumers (Noble et al., 2009; Lyons, 2016)Fig. 1. Prensky (2001) argued that Gen Y users are perceived as having an 'innate confidence in using new technologies such as the internet' and 'all the 
other toys and tools of the digital age' (p. 1). Selwyn (2009) even goes so far as to say that these individuals perceive technology as crucial to their existence.) Furthermore, they are a largely segmented audience who are more difficult to reach through traditional marketing interventions (Wallop, 2014; Isaac, 2016). This makes them fertile ground for research in terms of likelihood and propensity to engage with online auctions. Importantly, Gen Y represents the future for this shopping model: Parment (2013) argues that 'generational cohorts' have relatively stable values throughout their lifetime, and we therefore need a greater depth of understanding in relation to Gen Y's decision-making processes.

\section{Method}

\subsection{Survey measures}

The survey was designed to measure the extended TPB model (Armitage and Conner, 2001), and each of the predictors of attitude, SN, perceived control and self-efficacy was reflective of participants' perceived intention to use the eBay online auction service. All items were rated on a seven-point scale, with higher scores representing more online auction service use, more favourable attitudes, more positive social influence (SN), and more personal control (perceived Control) and ability (self-efficacy) with respect to using the eBay service.

TPB Measures. Intention was measured by three item statements which required participants to rate the likelihood of using the eBay service within the month - for example, 'How likely are you to use eBay ... ?' Attitudes towards eBay measured participants' favourable or unfavourable perceptions through six differential scale items: practical/ impractical, complicated/uncomplicated, appealing/unappealing, good idea/bad idea, valuable/worthless, and easy/difficult. Subjective norm $(S N)$ measured the importance of 'significant others' in endorsing eBay. Participants were asked to evaluate a single item statement: 'Most people who I know think that using eBay ... is a good idea.' Perceived Behavioural Control (PBC) was measured by nine items of which an example was ' $I$ would find using eBay as pretty straight forward when selling or buying an item'. Finally, behaviour measured participants' frequency of engaging with eBay through one item which was rated on an eight-point scale ranging from 'not at all' to 'daily'.

Trust and Security. Trust and Security items were employed to further extend the TPB model. A single item to measure trust was employed: ' $I$ don't trust a service like eBay when purchasing or selling an item.' Likewise, perceptions of security were measured by a single item: 'Providing personal information would discourage me from using eBay to buy or sell an item.'

\subsection{Sample, procedure and analysis}

The target audience for this study was Generation Y (Gen Y; born 1980-95). The survey was administered to a convenience sample of participants at a series of professional events taking place in Northern Ireland and the Republic of Ireland, set up to provide information to individuals seeking information on additional study opportunities. Convenience sampling is often used in online shopping studies and is widely acknowledged as a viable and suitable technique (Ramayah and Ignatius, 2005; Liao et al., 1999; Lu et al., 2011; Mohamed et al., 2014). The all-Ireland context of the survey was chosen to increase the robustness of the findings and the similarities across both Northern Ireland and Republic of Ireland consumers justifies this further (Kautonen et al., 2013). The researchers sought approval from the organisers to administer the questionnaires.

All participants received an instructional sheet demonstrating how to complete the survey. There were one hundred and fifty-four males ( $n=$ $154)$ and one hundred and ninety-two females $(n=192)$ who completed the survey. The average age for males was $34.94(S D=7.21)$ and 34.19 $(S D=6.40)$ for females. Both males $(41.1 \% ; n=69)$ and females $(41.1 \% ; n=79)$ used the online auction platform to buy things. Slightly more females $(82.2 \% ; \mathrm{n}=157)$ than males $(80.1 \% ; \mathrm{n}=121)$ used the service to sell items. Analysis was conducted in two phases.

In the first phase the multi-item TPB constructs assessed their factor structure and internal consistency. At this point the data was split randomly into two files. An Exploratory Factor Analysis (EFA) was carried out using the intention, attitudes and $\mathrm{PBC}$ constructs with associated Cronbach Alpha Coefficients. With the second phase a Confirmatory Factor Analysis (CFA) was carried out to confirm the factor structure based on the EFA results. Furthermore, a Pearson's Correlation Coefficient matrix was generated to examine the strength of associations between each of the TPB constructs. At the second phase descriptive and inferential statistics (t-test), along with path analysis models, were conducted for the male and female samples and compared in a multi-group analysis.

The evaluation of the path model fit followed the guidelines suggested by Hoyle and Panter (1995) and Miles and Shevlin (2007). The Chi-Square, Chi-Square/DF Ratio, the Normed Fit Index (NFI), Relative Fit Index (RFI), Incremental Fit Index (IFI), Tucker Lewis Index (TLI) and the Comparative Fit Index (CFI) were used to assess the adequacy of model fit. The Chi-Square statistic indicates an acceptable fit if the associated probability value is greater than the chosen level of alpha (0.05), the Chi-Square/DF Ratio should be less than 3, and the other indices should be greater than 0.90 (Miles and Shevlin, 2007; Kline, 2016). The Root Mean Error of Approximation (RMSEA: Steiger, 1990) was used to assess the fit of the models. An RMSEA value of 0.08 or below indicates satisfactory fit between the specified model and the sample data (Kline, 2016). However, regarding the CFA, Hu and Bentler (1999) and Schreiber et al. (2006) recommended the Chi-Square, Chi-Square/DF Ratio, TLI, CFI and RMSEA as appropriate fit indices. Additionally, they recommend the Standardised Root Mean Residual (SRMR). Values under 0.08 indicate a satisfactory fit (Hu and Bentler, 1999).

\section{Results}

\subsection{Exploratory factor analysis}

Three separate exploratory factor analysis (EFA) using Principle Axis Factoring with Direct Oblimin was employed; and only multiple item constructs of the TPB (Ajzen, 1991; 2015) were included. Factors with Eigenvalues over 1 were reported for each of the EFA's.

Intentions toward engaging with online auctions. Analysis reported a one-factor solution and accounted for $79.75 \%$ of variance explained (see Table 1). All three items had favourable factor loads (Field, 2009) and yielded a favourable level (Kline, 2000) of internal consistency $(\alpha=$ 0.87).

Attitudes towards online auctions. One factor emerged and accounted for $63.36 \%$ of variance explained. Results indicated that five of the six items tested all reported loading above the 0.4 level (Field, 2009) and only one failing to reach the desired level (see Table 2). Thus, attitudes towards engaging with online auctions fell into one factor with a

Table 1

Intention item loadings with associated alpha.

\begin{tabular}{|c|c|c|}
\hline & Statements: Intentions & $\begin{array}{l}\text { Factor } \\
\text { Loading }\end{array}$ \\
\hline $\begin{array}{c}\text { Item } \\
1\end{array}$ & $\begin{array}{l}\text { I intend to use eBay when I want to sell/purchase an item in } \\
\text { the next month }\end{array}$ & .90 \\
\hline $\begin{array}{c}\text { Item } \\
2\end{array}$ & $\begin{array}{l}\text { I intend to use eBay when I want to purchase/sell an item in } \\
\text { the next month. }\end{array}$ & .89 \\
\hline \multirow[t]{4}{*}{$\begin{array}{c}\text { Item } \\
3\end{array}$} & $\begin{array}{l}\text { How likely is it that you will use eBay to buy/sell a product } \\
\text { within the next month? }\end{array}$ & .71 \\
\hline & Eigenvalues & 2.39 \\
\hline & Percentage of variance explained & 79.57 \\
\hline & $\alpha$ & .87 \\
\hline
\end{tabular}


satisfactory (Kline, 2000) associated internal consistency $(\alpha=0.91)$.

PBC and online auction engagement. Regarding PBC, a two factor solution emerged which accounted $59.80 \%$ of variance (see Table 3 ). Analysis suggests that control perceptions around online auction sites fall into two distant factors. The first factor had four items and reflected confidence in an individual's or internal ability to engage with online auctions. This factor indicated self-efficacy. While, factor 2 was contained five items and indicted more perceived facilitators or barriers around engaging with online auction sites. Thus, this factor indicated perceived control. Overall, both self-efficacy $(\alpha=0.85)$ and perceived control $(\alpha=0.77)$ were reported to have favourable internal consistency (Kline, 2000). Overall, the findings of this analysis supports these factors as separated rotated variables rather than one variable for PBC.

\subsection{Confirmatory Factor Analysis}

The second step of the analysis examine the validity of the TPB components (intention, attitudes, SN, SE and PC). Confirmatory Factor Analysis (CFA) estimated the model fit of the proposed model. Results are presented in Fig. 2. Overall, the chi-square and the RMSEA suggest that the data describes the model adequately well $\left(X^{2}(184)=287.21, d f\right.$ $=113, p=.000, X^{2} / d f=2.54$, RMSEA $=0.09$, TFI $=0.87, \mathrm{CFI}=0.91$, SRMR $=0.07$ ). All of the standardised loadings were significant and ranged from moderate to strong (Miles and Shevlin, 2007; Kline, 2016).

\subsection{Correlations}

Zero-order correlations are presented in Table 4, and it is clear the strongest significant relationships with intentions to use the online auction site were with attitudes $(r=0.73, p<.001)$, self-efficacy $(r=$ $0.57, \mathrm{p}<.001)$, security $(\mathrm{r}=0.46, \mathrm{p}<.001)$ and trust $(\mathrm{r}=0.45, \mathrm{p}<$ $.001)$. Moderate to weaker significant relationships with intentions were reported perceived control $(\mathrm{r}=0.31, \mathrm{p}<.001)$ and $\mathrm{SN}(\mathrm{r}=0.31, \mathrm{p}<$ .05). Lastly, behaviour was significantly related moderately-strongly with intention $(\mathrm{r}=0.58, \mathrm{p}<.001)$, attitude $(\mathrm{r}=0.50, \mathrm{p}<.001)$, selfefficacy $(\mathrm{r}=0.51, \mathrm{p}<.001)$, trust $(\mathrm{r}=0.38, \mathrm{p}<.001)$, security $(\mathrm{r}=$ $0.38, \mathrm{p}<.001)$ and perceived control $(\mathrm{r}=0.29, \mathrm{p}<.001)$ while $\mathrm{SN}(\mathrm{r}=$ $0.20, \mathrm{p}<.001$ ) was significantly, yet weakly, related. Interestingly, the relationship between trust and security was significant but weak $(r=$ $.29, \mathrm{p}<.001$ ) suggesting construct independence. Since all the TPB independent variables were significantly related with the criterion variables this would support further exploration with path analysis.

\subsection{Gender differences and path models}

In order to test the equivalence of the extended TPB model for the female and male groups within the overall sample, a multi-group analysis was conducted. A comparison between the no restrictions model (extended TPB model tested simultaneously on both groups with latent means and regression paths varying freely) and the fully restricted model (latent means and regression paths restricted to be equal across gender groups) indicated a significant difference, $\chi^{2}(13)=26.66, p<.05$. This

Table 2

Attitude item loadings with associated alpha.

\begin{tabular}{lll}
\hline & Statements: Attitudes & Factor Loading \\
\hline Item 1 & Good idea/Bad idea & .92 \\
Item 2 & Appealing/Unappealing & .86 \\
Item 3 & Valuable/Worthless & .81 \\
Item 4 & Practical/Impractical & .80 \\
Item 5 & Easy/Difficult & .72 \\
Item 6 & Complicated/Uncomplicated & - \\
& & \\
& Eigenvalues & 3.80 \\
& Percentage of variance explained & 63.36 \\
& $\alpha$ & .91 \\
\hline
\end{tabular}

Table 3

Self-efficacy (1) and perceived control (2) item loadings with associated alphas.

\begin{tabular}{|c|c|c|c|}
\hline & \multirow[t]{2}{*}{ Statements: PBC } & \multicolumn{2}{|c|}{$\begin{array}{l}\text { Factor } \\
\text { Loading }\end{array}$} \\
\hline & & (1) & (2) \\
\hline $\begin{array}{c}\text { Item } \\
1\end{array}$ & $\begin{array}{l}\text { I would find using eBay as pretty straight forward when } \\
\text { selling or buying an item }\end{array}$ & .81 & \\
\hline $\begin{array}{c}\text { Item } \\
2\end{array}$ & $\begin{array}{l}\text { I would feel very confident within the next month to buy } \\
\text { or sell an item on eBay }\end{array}$ & .80 & \\
\hline $\begin{array}{c}\text { Item } \\
3\end{array}$ & $\begin{array}{l}\text { I know I would have the ability to use eBay within the } \\
\text { next month to sell or purchase a product }\end{array}$ & .74 & \\
\hline $\begin{array}{c}\text { Item } \\
4\end{array}$ & $\begin{array}{l}\text { I feel that I would encounter very few problems using } \\
\text { eBay to sell or buy an item to buy or sell an item }\end{array}$ & .67 & \\
\hline $\begin{array}{l}\text { Item } \\
5\end{array}$ & $\begin{array}{l}\text { In general I feel that I don't have enough of capacity } \\
\text { either selling or purchasing of an item on eBay if I were } \\
\text { to use it within the next month }\end{array}$ & & .62 \\
\hline $\begin{array}{c}\text { Item } \\
6\end{array}$ & $\begin{array}{l}\text { In general it would be difficult for me to be able to send } \\
\text { items, which I sold on eBay if I were to use it in the next } \\
\text { month }\end{array}$ & & .61 \\
\hline $\begin{array}{c}\text { Item } \\
7\end{array}$ & $\begin{array}{l}\text { In general it would be difficult for me to be able to } \\
\text { receive bought items from eBay if I were to use it in the } \\
\text { next month }\end{array}$ & & .60 \\
\hline $\begin{array}{c}\text { Item } \\
8\end{array}$ & $\begin{array}{l}\text { I feel using eBay in the next month to sell or buy an item } \\
\text { would take too much time }\end{array}$ & & .59 \\
\hline \multirow[t]{5}{*}{9} & $\begin{array}{l}\text { I feel that I have no control over the selling or } \\
\text { purchasing of an item on eBay if I were to use it within } \\
\text { the next month }\end{array}$ & & .53 \\
\hline & Eigenvalues & 3.63 & 1.75 \\
\hline & Percentage of variance & 40.38 & 19.42 \\
\hline & Percentage of variance explained & 59.80 & \\
\hline & $\alpha$ & .85 & .77 \\
\hline
\end{tabular}

suggests that there was a significant difference between female and male samples in relation to latent means and regression paths within the TPB model tested. This justifies the treatment of the female and male groups as separate samples when testing the extended TPB model.

Descriptive statistics (see Table 5) trends for intentions (Male: $M=$ 13.93, $S D=5.58$; Female: $M=14.68, S D=5.68$ ), attitudes (Male: $M=$ 18.35, $S D=7.63$; Female: $M=18.70, S D=7.90$ ), self-efficacy (Male: $M$ $=15.70, S D=7.34$; Female: $M=15.98, S D=7.81$ ) and perceived control (Male: $M=21.13, S D=7.70$; Female: $M=19.90, S D=7.75$ ) to using eBay to sell or buy were all moderately favourable for both genders; though SN (Male: $M=2.81, S D=1.38$; Female: $M=2.92, S D=$ 1.56) was reported to be less than favourable. Frequency of behaviour using eBay was very favourable (Male: $M=6.79, S D=1.34$; Female: $M$ $=6.71, S D=1.47$ ) overall. Interestingly, trust (Male: $M=3.85, S D=$ 2.05; Female: $M=3.31, S D=1.97$ ) and security (Male: $M=3.07, S D=$ 1.82; Female: $M=3.02, S D=1.76$ ) perceptions using eBay were less than favourable, moreover, significantly less favourable in relation to trust $(t(340)=2.49, p=.013)$.

\subsection{Estimation of the extended TPB model}

Path analysis tested the extended TPB model for both males (Fig. 3) and females (Fig. 4) and the overall fit of the models (see Table 6) suggested a good explanation of the relationships within the data (Male: $X^{2}(154)=0.61, d f=2, p=.738, X^{2} / d f=0.30$, RMSEA $=0.00 ;$ Female: $X^{2}(192)=0.88, d f=2, p=.646, X^{2} / d f=0.44$, RMSEA $\left.=0.00\right)$. All chisquare values with associated degrees of freedom were low and nonsignificant and all values associated with the $X^{2} / d f$ ratio were less than 3 (Kline, 2016); and the RMSEA was less than 0.05 (Browne and Cudeck, 1993; Hu and Bentler, 1999). Incremental fit indices were employed to evaluate the model fit (Hoyle and Panter, 1995; Hu and Bentler, 1999; Miles and Shevlin, 2007; Kline, 2016) to both data groups. The values indicated that the NFI $($ Male $=0.99 ;$ Female $=0.99)$, RFI $($ Male $=0.98 ;$ Female $=0.98)$, CFI $($ Male $=1.00 ;$ Female $=1.00)$, and IFI $($ Male $=1.00 ;$ Female $=1.00)$, TLI $($ Male $=1.00 ;$ Female $=1.00)$ were all greater than the 0.95 cut off point; both tested models provided a 


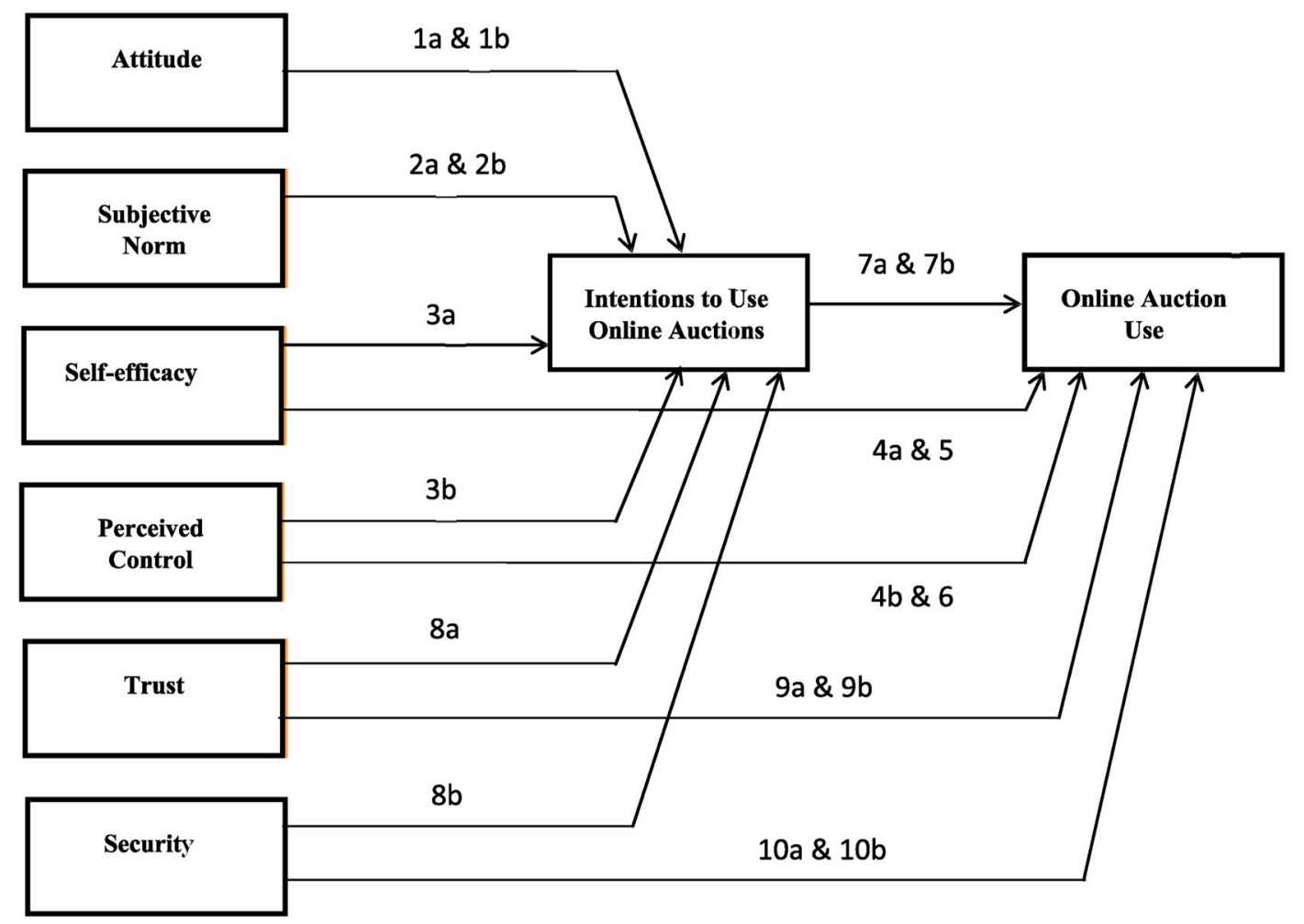

Fig. 1. Proposed model to be tested with associated hypotheses.

good approximation and explanation of the data (Miles and Shevlin, 2007; Kline, 2016).

Figs. 3 and 4, along with Table 6, illustrate the predictor variable influences on intentions and behaviours for both male and female models. Regards to males, attitudes $(\beta=0.48 ; p<.001)$ and self-efficacy $(\beta=0.24, p<.01)$ had significant influences on intentions, with attitude $\mathrm{s}$ being the strongest predictor of intentions to use eBay. However, $\mathrm{SN}(\beta$ $=-0.08, p>.05)$, perceived control $(\beta=0.02, p>.05)$, trust $(\beta=0.14$, $p<.05)$ and security $(\beta=0.09, p>.05)$ failed to have a significant influence on intentions. These factors accounted for $59 \%\left(R^{2}=0.59\right)$ of variance in intentions to use eBay. Female intentions to use eBay were significantly predicted mostly by attitudes $(\beta=0.58 ; p<.001)$ and trust $(\beta=0.18, p<.05)$. SN $(\beta=0.02, p>.05)$, self-efficacy $(\beta=0.00, p>$ $.05)$, perceived control $(\beta=0.02, p>.05)$ and security $(\beta=0.11, p>$ .05 ) were not reported to be significant. These factors accounted for $56 \%$ $\left(R^{2}=0.56\right)$ of the variance explained in intentions. Since there was more variance explained of male intentions compared to females, the model for males had more explanatory power.

With regards to predicting behaviour within males, intentions $(\beta=$ $0.38, p<.001$ ) had the strongest significant influence on behaviour, followed by self-efficacy $(\beta=0.28, p<.001)$ and perceived control $(\beta=$ $0.19, p<.05)$. Trust $(\beta=-0.03, p>.05)$ and security $(\beta=-0.03, p>$ .05 ) failed to have a significant influence on behaviour; however, the factors within the model account for $62 \%\left(R^{2}=0.46\right)$ of the variance explained. In contrast, several factors significantly predicted behaviour within the model for females, this included intentions $(\beta=0.39, p<$ $.001)$, self-efficacy $(\beta=0.24, p<.01)$ and security $(\beta=0.13, p<.05)$. Perceived control $(\beta=-0.15, p>.05)$ and trust $(\beta=0.14, p>.05)$ failed to research statistical significance. These factors accounted for $43 \%\left(R^{2}\right.$ $=0.43$ ) of the variance on behaviour.

The table below (see Table 7) provides a description of whether each hypothesis was supported, partially support or not support based on the research findings.

\section{Discussion}

The central aim of this research was to further understand the gap between Gen Y males and Gen Y females in their perceptions, attitudes and behaviours regarding usage of online auction sites such as eBay (Black, 2005, 2007; Lai et al., 2008; Wang and Zhang, 2012), using an extended (Conner and Armitage, 1998; Chen et al., 2007) TPB model (Ajzen, 1991). Overall, the findings supported the use of the extended TPB model, as they provided a parsimonious explanation of the data for both gender groups (Hoyle and Panter, 1995; Miles and Shevlin, 2007), thus supporting the utility of TPB in explaining and predicting eBay engagement intentions and online auction usage, similar to other online behaviours (Lee, 2009; Yousafzai et al., 2010; Burns and Roberts, 2013). Below, hypotheses surrounding the extended TPB are discussed against current research findings.

\subsection{Predicting online auction intentions and engagement}

Consistent with what had been hypothesised (H1), attitudes towards eBay had the strongest influence on transaction intentions for both males and females, suggesting that more positive attitudes towards the service would predict a greater likelihood of the intention to engage with online auctions. Interestingly, this attitudinal driver was more influential in predicting female intentions than male intentions, thus, supporting the present authors' hypothesis (H1b) and past research (Pavlou and Fygenson, 2006; Lai et al., 2008; Huang et al., 2011; Riedl et al., 2010; Wang and Zhang, 2012; Zhou et al., 2014; Hou and Elliott, 2016). Previously, females have been reported as attaching more importance to the enjoyment of the experience, the availability of bargains, and the value of the experience than males engaging with eBay, and the present findings would support this. However, these findings would seem to contradict those of Nadeem et al. (2015), who proposed that the gender gap is 'diminishing' regarding online presence, although this was in the context of social media engagement. Furthermore, it contradicts the position, proposed by Vicente (2015), that females are 


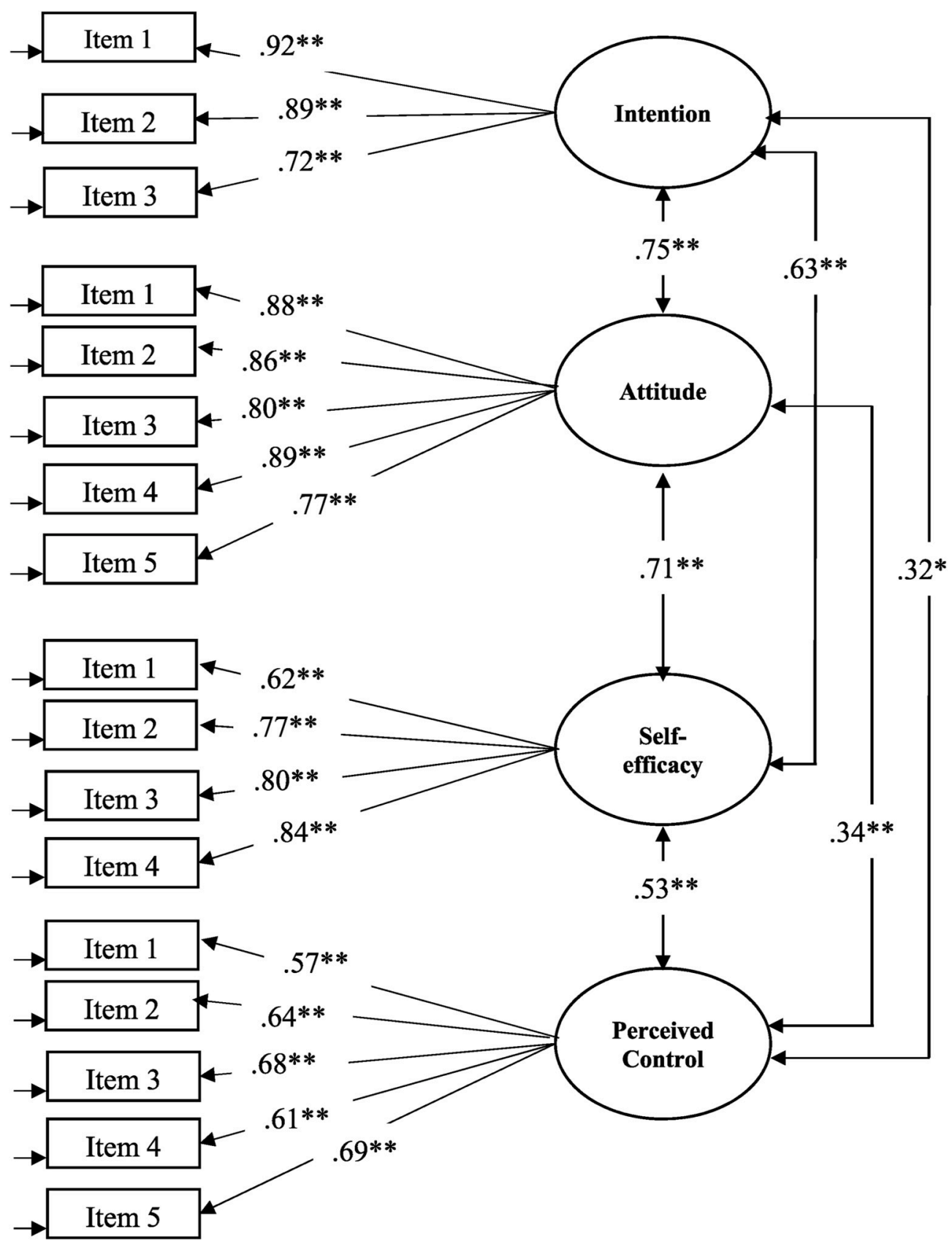

Note: * significant at the .05 level; ** significant at the .001 .

Fig. 2. CFA model employing TPB items.

Table 4

Correlations between selected TPB variables.

\begin{tabular}{|c|c|c|c|c|c|c|c|c|}
\hline Variables & 1 & 2 & 3 & 4 & 5 & 6 & 7 & 8 \\
\hline 1. Intentions & - & & & & & & & \\
\hline 2. Attitude & $.73^{* *}$ & - & & & & & & \\
\hline 3. SN & $.31^{* *}$ & $.39 * *$ & - & & & & & \\
\hline 4. Self-Efficacy & $.57 * *$ & $.64 * *$ & $.38^{* *}$ & - & & & & \\
\hline 5. Perceived Control & $.31 * *$ & $.30 * *$ & .01 & $.39 * *$ & - & & & \\
\hline 6. Trust & $.45^{* *}$ & $.41^{* *}$ & $.16^{* *}$ & $.44^{* *}$ & $.51^{* *}$ & - & & \\
\hline 7. Security & $.46^{* *}$ & $.50 * *$ & $.44^{* *}$ & $.50^{* *}$ & $.21^{* *}$ & $.29^{* *}$ & - & \\
\hline 8. Online Auction Use & $.58 * *$ & $.50 * *$ & $.20^{* *}$ & $.51^{* *}$ & $.29 * *$ & $.38^{* *}$ & $.38^{* *}$ & _ \\
\hline
\end{tabular}


Table 5

Descriptive statistics, t-values and associated significance scores.

\begin{tabular}{|c|c|c|c|c|c|c|}
\hline & Male & & Female & & & \\
\hline Variables & $M$ & $S D$ & $M$ & $S D$ & $t$ & $p$ \\
\hline Intention & 13.93 & 5.58 & 14.68 & 5.68 & -1.22 & .225 \\
\hline Attitude & 18.35 & 7.63 & 18.70 & 7.90 & -.41 & .684 \\
\hline SN & 2.81 & 1.38 & 2.92 & 1.56 & -.70 & .487 \\
\hline Self-efficacy & 15.70 & 7.34 & 15.98 & 7.81 & -.35 & .729 \\
\hline Perceived control & 21.13 & 7.70 & 19.90 & 7.75 & 1.45 & .148 \\
\hline Online Auction Use & 6.79 & 1.34 & 6.71 & 1.47 & .50 & .614 \\
\hline Trust & 3.85 & 2.05 & 3.31 & 1.97 & 2.49 & .013 \\
\hline Security & 3.07 & 1.82 & 3.02 & 1.76 & -1.14 & .255 \\
\hline
\end{tabular}

Note: * Sig at 0.05 level.

less inclined to engage with online auctions than males. In contrast, SN failed to have a significant influence $(\mathrm{H} 2 \mathrm{a}, \mathrm{b})$ in either of the two tested models, suggesting that the role of positive or negative social pressure proved consistent with previous findings (Huang et al., 2011) for both the males or females in the sample. This is in contrast to previous studies that reported that social influences have an impact on online auction intentions (Pavlou and Fygenson, 2006; Pahnila et al., 2011).

Interestingly, the results indicated that the role of self-efficacy and perceived control predicting auction engagement intentions did not fully support the stated hypotheses ( $\mathrm{H} 3 \mathrm{~b}$ and $\mathrm{H} 4 \mathrm{a}$ ), rather both factors had an impact on intentions, but only for males (H3a and H4b). Likewise, consistent with the stated hypothesis, it was only within the male sample that self-efficacy (H5) and perceived control (H6) had any significant role in predicting online auction usage. These findings have support in findings previously proposed by Swaminathan et al. (1999), Black (2007) and Huang et al. (2011), suggesting that abilities, and confidence, do have a role to play in driving online engagement. More explicitly, it suggests that male self-efficacy has a dual role in informing decisions and usage of eBay, with only perceived control influencing their usage of such online auctions. Basically, males are more involved with planning (Yeh et al., 2012; Hou and Elliott, 2016) and are more confident (Stafford et al., 2004), which positively impacts their online auction engagements. Browsing, buying or selling items on eBay for males is not dependent solely on positive decisions, but also on their being more efficacious (Pavlou and Fygenson, 2006; Huang et al., 2011) and perceiving fewer barriers (Pavlou and Fygenson, 2006).

Although self-efficacy (H5) and perceived control (H6) had some impact on auction usage within the male sample, it was intentions that was reported to have the strongest influence on online auction usage (H7a), for both males and females, which is consistent with previous findings. That is, individuals' intentions about using eBay was the best indicator or their usage, which supports other findings (Pavlou and Fygenson, 2006; Huang et al., 2011). However, female sample intentions were reported to have a stronger influence on their usage of eBay than the male sample (H7b), though only slightly. Previously, TPB has often been applied to measure antecedents of intentions, and not behaviour (Yen and Lu, 2008), so these findings provide valuable information for understanding the drivers of online auction engagement (Ajzen, 2015).

\subsection{The role of trust and security perceptions}

Importantly, the research explored the role of both trust and security perceptions of consumers within the model. What was reported indicated that trust did have a significant influence on consumers' intentions to use online auctions (8a) but not online auction usage (9a), although only in regards to females and not males (9b) as hypothesised. Similarly, security failed to have a significant influence on online auctions usage intention (8b) but had a significant influence directly on online auction usage (10a), and once again only for females and not males (10b). What

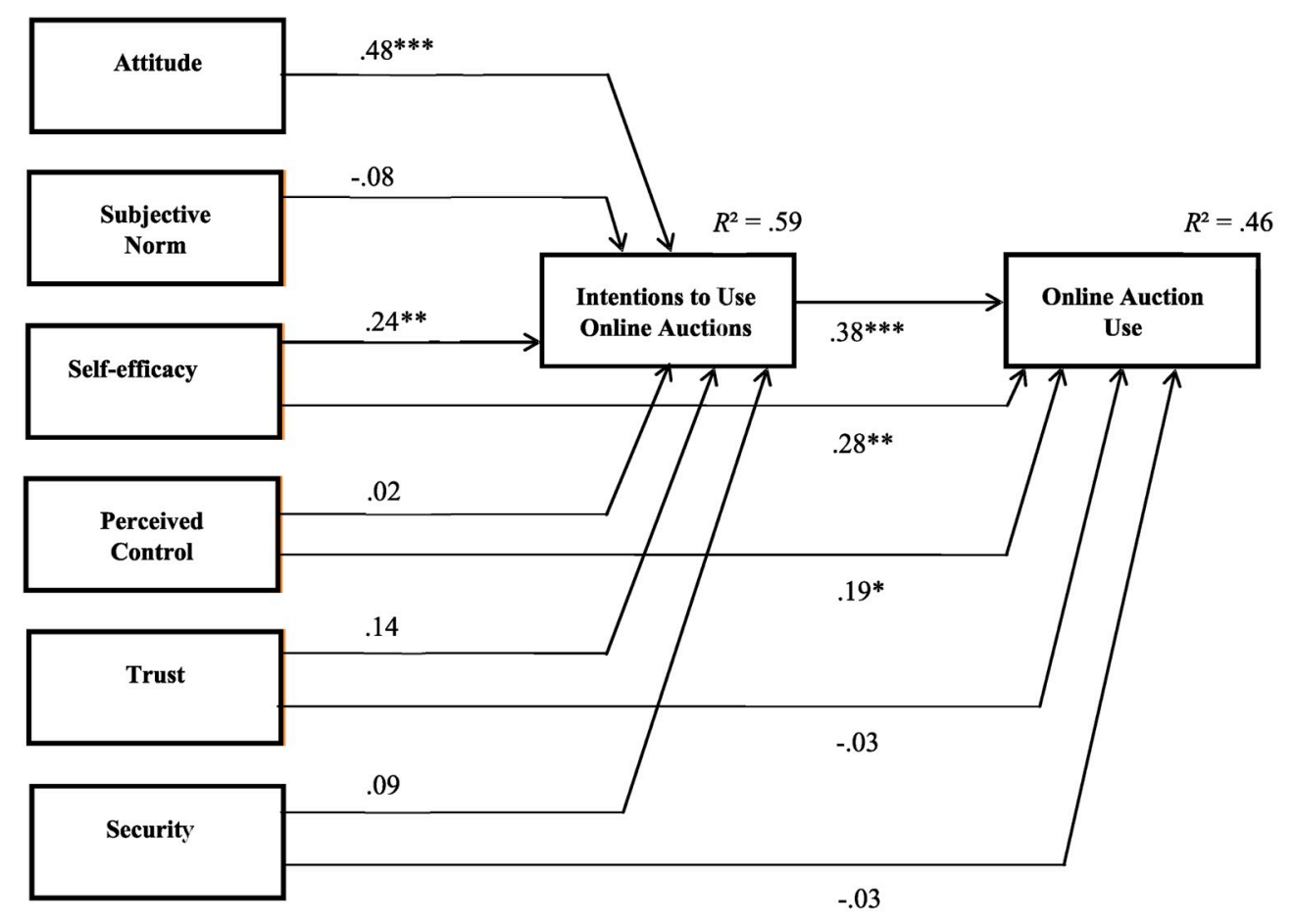

Note: * significant at the .05 level; ** significant at the .01 level; *** significant at the .001

Fig. 3. Path diagram of extended TPB model for males. 


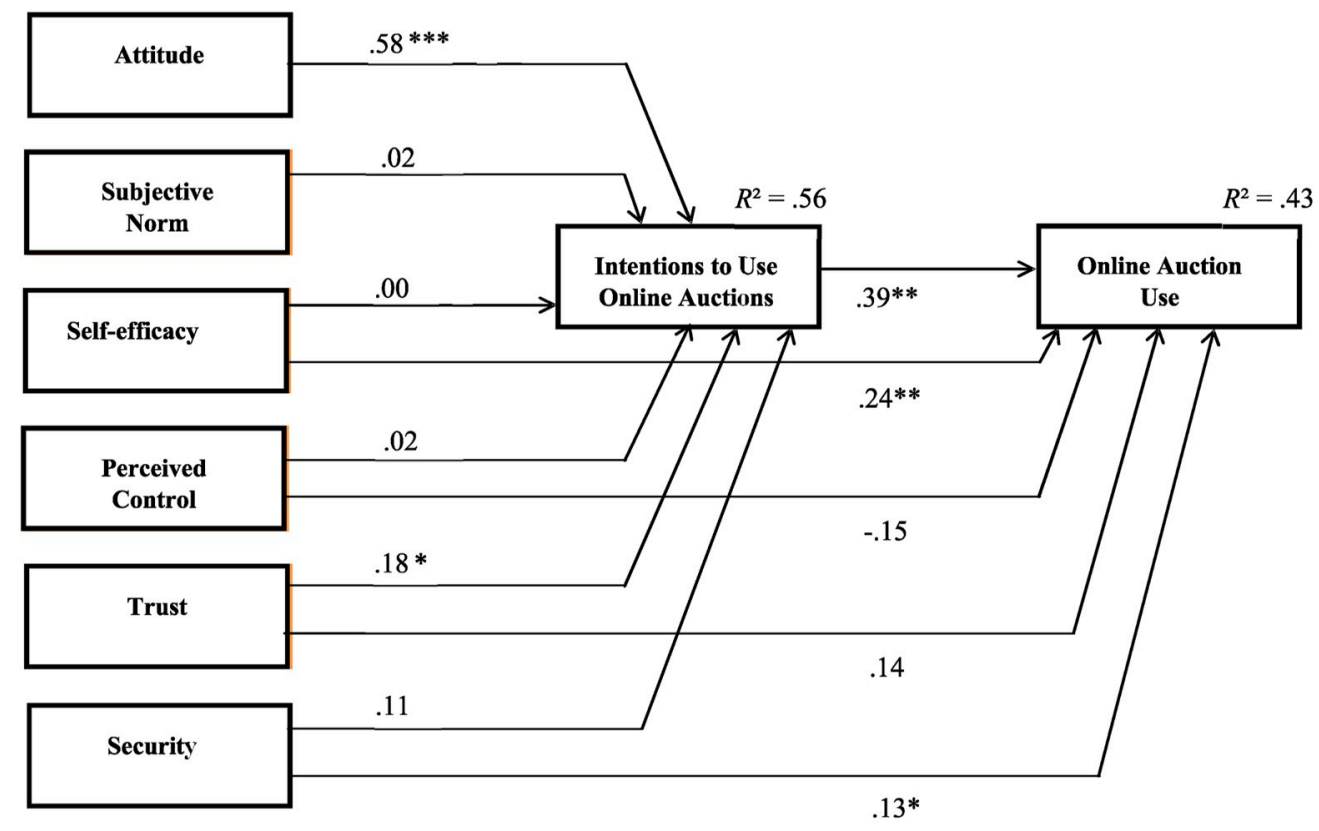

Note: * significant at the .05 level; ** significant at the .01 level; ${ }^{* * *}$ significant at the .001 .

Fig. 4. Path diagram of extended TPB model for females.

Table 6

Fit and statistics and path coefficients for both male and female models.

\begin{tabular}{|c|c|c|c|c|c|c|c|c|}
\hline \multirow[b]{2}{*}{ Path } & & & \multicolumn{3}{|c|}{ Male } & \multicolumn{3}{|c|}{ Female } \\
\hline & & & $\overline{R^{2}}$ & $\beta$ & $p$ & $\overline{R^{2}}$ & $\beta$ & $p$ \\
\hline Attitude & $\rightarrow$ & Intention & & .48 & .000 & & .58 & .000 \\
\hline SN & $\rightarrow$ & Intention & & -.08 & .211 & & .02 & .566 \\
\hline Self-efficacy & $\rightarrow$ & Intention & .59 & .24 & .001 & .56 & .00 & .708 \\
\hline $\begin{array}{c}\text { Perceived } \\
\text { control }\end{array}$ & $\rightarrow$ & Intention & & .02 & .843 & & .02 & .902 \\
\hline Trust & $\rightarrow$ & Intention & & .14 & .095 & & .18 & .007 \\
\hline Security & $\rightarrow$ & Intention & & .09 & .200 & & .11 & .080 \\
\hline Intention & $\rightarrow$ & Behaviour & & .38 & .000 & & .39 & .000 \\
\hline Self-efficacy & $\rightarrow$ & Behaviour & .46 & .28 & .000 & .43 & .24 & .002 \\
\hline $\begin{array}{r}\text { Perceived } \\
\text { control }\end{array}$ & $\rightarrow$ & Behaviour & & .19 & .040 & & -.15 & .050 \\
\hline Trust & $\rightarrow$ & Behaviour & & -.03 & .742 & & .14 & .068 \\
\hline Security & $\rightarrow$ & Behaviour & & -.03 & .692 & & .13 & .048 \\
\hline$X^{2}$ & & & & .61 & & .88 & & \\
\hline Df & & & & 2 & & 2 & & \\
\hline$X^{2} / \mathrm{df}$ & & & & .30 & & .44 & & \\
\hline$P$ & & & & .738 & & .646 & & \\
\hline RMSEA & & & & .00 & & .05 & & \\
\hline CFI & & & & 1.00 & & 1.00 & & \\
\hline IFI & & & & 1.00 & & 1.00 & & \\
\hline TLI & & & & 1.00 & & 1.00 & & \\
\hline RFI & & & & .98 & & .98 & & \\
\hline NFI & & & & .99 & & .99 & & \\
\hline
\end{tabular}

the evidence suggests is that both trust and security play some role in predicting consumers engagement with online auctions and by doing so supports past findings (Garbarino and Strahilevitz, 2004; Croson and Gneezy, 2009; Shareef et al., 2013). However, what the research does identify is the role that trust and security play in how female consumers engage with online auctions. Evidence suggests that trust impacts on the decision making processing around online auctions whilst perceptions of security influence actual usage. Even though single items were employed within this research to measure both trust and security. Previous research does support the performance and adequacy of using single items to measure key constructs (Doorn et al., 2010; Leisen Pollack and Alexandrov, 2013). Findings suggested that both constructs are not only distinct but also have two distinct roles regarding consumers using online auctions; trust impacting at a decision making level while security at a behavioural. Though, more research would need to conducted, what it does support is that females may be more likely to evaluate the risk of using online auctions than males (Garbarino and Strahilevitz, 2004; Croson and Gneezy, 2009).

\section{Implications, future research directions and conclusions}

There are several theoretical and practical implications that can be drawn from this research. Current research findings indicate that application of models such as TPB provide an opportunity for an integrated exploration of eBay engagement decisions and usage, thereby further advancing our understanding of online auction behaviours. Importantly, this study demonstrates the relevance and explanatory power of TPB in different contexts and answers the call by Hou and Elliott (2016) to examine established theories, like TPB, in terms of their relevance and utility regarding online auction sites. Furthermore, in the past, males were reported to be less apprehensive of e-business behaviours compared to females (Stafford et al., 2004), and relatedly, the current findings lend insight into the role of abilities and confidence which could underlie this female apprehension around online behaviours.

The current study also supports recent findings that suggested attitudes are more important in prediction of females' intentions (Riedl et al., 2010), suggesting that more positive attitudes held by females will in turn be more likely to impact on their online transaction intentions than in male cases. Although Riedl et al. (2010) applied experimental neuropsychological techniques, the current study findings complement their findings, thus strengthening the value of attitudes as an antecedent of online transaction decisions.

It was quite surprising to find that social pressures failed to influence individuals' decisions, as it has been widely thought that social pressures 
Table 7

Research hypotheses.

\begin{tabular}{|c|c|c|}
\hline Hypotheses & Hypothesis description & Findings \\
\hline $1 \mathrm{a}$ & $\begin{array}{l}\text { Favourable attitudes towards online auctions will } \\
\text { significantly predict greater intentions to engage with } \\
\text { online auction sites }\end{array}$ & Supported \\
\hline $1 b$ & $\begin{array}{l}\text { Favourable attitudes towards online auctions will } \\
\text { significantly predict greater intentions to engage with } \\
\text { online auction sites; the female sample reporting a } \\
\text { stronger positive link between the variables }\end{array}$ & Supported \\
\hline $2 a$ & $\begin{array}{l}\text { Favourable social influences will significantly predict } \\
\text { greater intentions to engage with online auction sites }\end{array}$ & Not supported \\
\hline $2 b$ & $\begin{array}{l}\text { Favourable social influences will significantly predict } \\
\text { greater intentions to engage with online auction sites; } \\
\text { the female sample reporting a stronger positive link } \\
\text { between the variables. }\end{array}$ & Not supported \\
\hline $3 a$ & $\begin{array}{l}\text { Higher levels of self-efficacy will significantly predict } \\
\text { more favourable intentions to use online auctions }\end{array}$ & $\begin{array}{l}\text { Partially } \\
\text { Supported }\end{array}$ \\
\hline $3 b$ & $\begin{array}{l}\text { Higher levels of perceived control will significantly } \\
\text { predict more favourable intentions to use online } \\
\text { auctions }\end{array}$ & Not supported \\
\hline $4 a$ & $\begin{array}{l}\text { Higher levels of self-efficacy will significantly predict } \\
\text { greater use of online auction sites }\end{array}$ & Supported \\
\hline $4 \mathrm{~b}$ & $\begin{array}{l}\text { Higher levels of perceived control will significantly } \\
\text { predict greater use of online auction sites }\end{array}$ & $\begin{array}{l}\text { Partially } \\
\text { supported }\end{array}$ \\
\hline 5 & $\begin{array}{l}\text { Male sample self-efficacy will have a stronger positive } \\
\text { link with using online auction sites compared to the } \\
\text { female sample }\end{array}$ & Supported \\
\hline 6 & $\begin{array}{l}\text { Male sample perceived control will have a stronger } \\
\text { positive link with using online auction sites compared } \\
\text { to the female sample }\end{array}$ & Supported \\
\hline $7 a$ & $\begin{array}{l}\text { Favourable intentions to engage with online auctions } \\
\text { will significantly predict greater use of online auction } \\
\text { sites }\end{array}$ & Supported \\
\hline $7 \mathrm{~b}$ & $\begin{array}{l}\text { Favourable intentions to engage with online auctions } \\
\text { will significantly predict greater use of online auction } \\
\text { sites; the male sample reporting a stronger positive link } \\
\text { between the variables }\end{array}$ & Not supported \\
\hline $8 a$ & $\begin{array}{l}\text { Favourable ratings of trust towards online auctions will } \\
\text { significantly predict greater intentions of use online } \\
\text { auction sites }\end{array}$ & $\begin{array}{l}\text { Partially } \\
\text { Supported }\end{array}$ \\
\hline $8 b$ & $\begin{array}{l}\text { Favourable ratings of security towards online auctions } \\
\text { will significantly predict greater intentions of use online } \\
\text { auction sites }\end{array}$ & Not supported \\
\hline $9 a$ & $\begin{array}{l}\text { Favourable ratings of trust towards online auctions will } \\
\text { significantly predict greater online auction sites usage }\end{array}$ & Not supported \\
\hline $9 b$ & $\begin{array}{l}\text { Favourable ratings of trust towards online auctions will } \\
\text { significantly predict greater online auction sites usage; } \\
\text { the male sample reporting a stronger positive link } \\
\text { between the variable }\end{array}$ & Not supported \\
\hline $10 \mathrm{a}$ & $\begin{array}{l}\text { Favourable ratings of security towards online auctions } \\
\text { will significantly predict greater online auction sites } \\
\text { usage }\end{array}$ & $\begin{array}{l}\text { Partially } \\
\text { supported }\end{array}$ \\
\hline $10 \mathrm{~b}$ & $\begin{array}{l}\text { Favourable ratings of security towards online auctions } \\
\text { will significantly predict greater online auction sites } \\
\text { usage; the male sample reporting a stronger positive } \\
\text { link between the variables }\end{array}$ & Not supported \\
\hline
\end{tabular}

have a significant impact on online transaction decisions (Swaminathan et al., 1999; Pahnila et al., 2011; Drake et al., 2012). The implications of this finding would suggest further exploration of social pressures is needed, especially with the growing influence of social media and of salient others (SN), such as family or friends. Research indicates that females, more so than males, spend longer periods of time engaged with social media than males (Ipsos, 2013), suggesting that these factors could be measured as antecedents of online auction decisions. This study provides a foundation for future researchers to study consumer behaviour in online auction sites and encourages the use of developed models such as TPB to support this. In addition, this study contributes to furthering our understanding around the complex relationship between intentions, behaviours and gender when participating in online auctions and retailing. Theoretically this study has demonstrated that consumer behaviour is a complex phenomenon which is shaped by various consumer, technology and environmental nuances that need to be considered such as online platform, gender, perceptions and intentions which mean that we are increasingly moving, with future research, to exploring bespoke behaviour models that are sympathetic to these variables. Future research can build upon the findings of this exploratory work by expanding, examining and evaluating existing consumer behaviour models such as 'Rational Economic Man' (Zinkhan, 1992), the 'Psychodynamic' tradition as developed by Freud originally (1856-1939) or the Stimulus-Organism-Response Model of Decision Making, (Foxall, 1993; Cziko, 2000). This study can essentially act as a foundation and catalyst for further exploration in future research.

The findings from this research inform managers decisions and choices around promoting auction platforms, security, trustworthiness and how to encourage different gender segments to engage and commit to the online auction channel for both buying and selling. This is critical as Hughes et al. (2018) argued that we need to develop knowledge, which is more specific and relevant by "consideration of the different contexts in which aspects of marketing are practices" (p. 9). This informs directly the messages involved in advertising - what the key variables should be to ensure that consumers are comfortable and engage with the online auction platform regularly to deliver economic and profit benefit. As organisations are increasingly trying to develop consumer based strategies intelligence, through the findings delivered through the current study, are critical so that the retailer/provider, and in this case the auction platforms, can provide additional value to consumers which directly influences their behaviours and choices, (Seybold, 2001; Hamilton and Price, 2019). This intelligence around consumer behaviour specifically allows existing incumbents in online auction platforms such as eBay to develop a competitive advantage in the market by creating more informed and sustained relationships with customers to establish loyalty based on intentions and behaviours. Finally this study practically informs segmented targeting and positioning in marketing and communications using the role of gender to deliver greater persuasion and impact on target consumer groups.

Owing to differences in how both groups perceive, and respond to, trust and security, consumer strategies to facilitate consumer engagement can be more carefully tailored to inform males and females visà-vis these issues differently. Previous attempts to reassure customers in these areas may have been ineffective due to the lack of understanding of the influencing role of gender. In fact, personal communications such as recommendations and word of mouth are likely to significantly influence consumers more in this environment due to the risk concerns. Establishing and maintaining a strong social media presence may be able to facilitate this electronic reassurance.

Overall, the current study has clearly demonstrated the utility of the TPB in understanding and improving engagement with online auction sites. Future market research could use approaches such as the TPB while extending the model using other drivers and applying within diverse shopping ecosystems and locations. Additionally, further multigroup analysis could explore possible differences between buyer, seller and buyer-seller groups (Foster and Tang, 2006), as little research has been conducted in this area. Lastly, other external factors should be examined regarding non-conventional shopping practices such as eBay and other online auctions, as they could also drive decisions and behaviours.

\section{Funding}

None.

\section{Declaration of competing interest}

The authors declare that there is no conflict of interest.

\section{Acknowledgements}

None. 


\section{Appendix A. Supplementary data}

Supplementary data to this article can be found online at https://doi. org/10.1016/j.jretconser.2020.102181.

\section{References}

Abdelghaffar, H., Moustafa, H., 2013. Exploring the factors affecting the intention to use C2C auction websites in Egypt. Int. J. E-Adoption (IJEA) 5 (2), 1-13. https://doi. org/10.4018/jea.2013040101.

Ajzen, I., 1991. The theory of planned behavior. Organ. Behav. Hum. Decis. Process. 50, 179-211. https://doi.org/10.1016/0749-5978(91)90020-t.

Ajzen, I., 2015. Consumer attitudes and behavior: the Theory of Planned Behavior applied to food consumption decisions. Riv. Econ. Agrar. 70 (2), 121-138. https:// doi.org/10.13128/REA-18003. Available at:, Accessed: 28 November 2018.

Armitage, C.J., Conner, M., 2001. Efficacy of the theory of planned behaviour: a metaanalytic review. Br. J. Soc. Psychol. 40 (4), 471-499. https://doi.org/10.1348/ 014466601164939.

Bae, S., Lee, T., 2011. 'Gender differences in consumers' perception of online consumer views'. Electron. Commer. Res. 11 (2), 201-214. https://doi.org/10.1007/s10660010-9072-y.

Baker, J., Wakefield, K.L.J., 2012. How consumer shopping orientation influences perceived crowding, excitement, and stress at the all. J. Acad. Market. Sci. 40 (6), 791-806. https://doi.org/10.1007/s11747-011-0284-z.

Black, G.S., 2005. Is eBay for everyone? An assessment of consumer demographics. SAM Adv. Manag. J. 70 (1), 50-59. Available at: https://www.questia.com/. Accessed: 10 July 2018.

Black, G.S., 2007. Consumer demographics and geographics: determinants of retail success for online auctions. J. Target Meas. Anal. Market. 15 (2), 93-102. https:// doi.org/10.1057/palgrave.jt.5750035.

Bolton, R.N., Parasuraman, A., Hoefnagels, A., Migchels, N., Kabadayi, S., Gruber, T., 2013. Understanding Generation $Y$ and their use of social media: a review and research agenda. J. Service Manag. 24 (3), 245-267. https://doi.org/10.1108/ 09564231311326987.

Bosnjak, M., Obermeier, D., Tuten, T.L., 2006. Predicting and explaining the propensity to bid in online auctions: a comparison of two action-theoretical models. J. Consum. Behav. 5 (2), 102-116. https://doi.org/10.1002/cb.38.

Browne, M.W., Cudeck, R., 1993. 'Alternative ways of assessing model fit'. In: Bollen, K. A., Long, J.S. (Eds.), Testing Structural Equation Models, pp. 136-162 (Beverly Hills, CA: Sage).

Burns, S., Roberts, L., 2013. Applying the Theory of Planned Behaviour to predicting online safety behaviour. Crime Prev. Community Saf. Int. J. 15 (1), 48-64. https:// doi.org/10.1057/cpcs.2012.13.

Carpenter, J., Moore, M., 2006. Consumer demographics, store attributes, and retail format choice in the US grocery market. Int. J. Retail Distrib. Manag. 34 (6), 434-452. https://doi.org/10.1108/09590550610667038.

Carroll, B., 2008. Social shopping: a new twist on e-commerce. Furniture-Today 32 (20), 81.

Chandra, C.P., 2015. The adoption of e-auction in Indonesia: the extended technology acceptance model study. iBuss Manag. 3 (2), 423-433.

Chen, R.-S., Chiu, C.-C., Chiang, J.-C., Tsai, C.-H., 2007. Research on the purchase behavior of customer-to-customer online auction. J. Bus. Publ. Aff. 1 (2), 1-8, 10.1.1.129.7579.

Clausen, J., Blättel-Mink, B., Erdmann, L., Henseling, C., 2010. Contribution of online trading of used goods to resource efficiency: an empirical study of eBay users. Sustainability 2 (6), 1810-1830. https://doi.org/10.3390/su2061810.

Conner, M., Armitage, C.J., 1998. Extending the Theory of Planned Behavior: a review and avenues for further research. J. Appl. Soc. Psychol. 28 (15), 1429-1464. https:// doi.org/10.1111/j.1559-1816.1998.tb01685.x.

Croson, R., Gneezy, U., 2009. Gender differences in preferences. J. Econ. Lit. 47 (2), 448-474. https://doi.org/10.1257/jel.47.2.448.

Cziko, G., 2000. The Things We Do: Using the Lessons of Bernard and Darwin to Understand the what, How, and Why of Our Behavior. MIT Press, Massachusetts.

Dittmar, H., Long, K., Meek, R., 2004. Buying on the internet: gender differences in online and conventional buying motivation. Sex. Roles 50 (5-6), 423-444. https://doi. org/10.1023/B:SERS.0000018896.35251.c7.

Doorn, J.V., Lemon, K.N., Mittal, V., Pick, D., Pirner, P., Verhoef, P.C., 2010. Customer engagement behavior: theoretical foundations and research directions. J. Serv. Res. 13 (3), 253-266. https://doi.org/10.1177/1094670510375599.

Drake, J.R., Hall, D.J., Byrd, T.A., 2012. The importance of individual characteristics on consideration sets for online auction buyers. J. Ther. Appl. Electron. Comm. Res. 7 (2), 13-30. https://doi.org/10.4067/S0718-18762012000200003.

eBay Inc, 2019. Reports first quarter 2019 results. Available at: https://www.ebayinc. com/. Accessed: 2 May 2019.

Fan, Y.W., Miao, Y.F., 2012. Effect of electronic word-of-mouth on consumer purchase intention: the perspective of gender differences. Int. J. Electron. Bus. Manag. 10 (3), 175-181. Available at: http://ijebm.ie.nthu.edu.tw/. Accessed: 11 October 2017.

Field, A., 2009. Discovering Statistics Using SPSS, third ed. Sage Publications Ltd., London.

Foster, P.W., Tang, Y., 2006. Mobile auctions: will they come? Will they pay? Emerg. Trends and Challeng. Inf. Technol.?Manag. 1 (2). Available at: http://www.irma -international.org/. Accessed: 15 March 2016.

Foxall, G., 1993. Situated consumer behaviour: a behavioral interpretation of purchase and consumption. Res. in Cons. Behav. 6, 113-152.
Garbarino, E., Strahilevitz, M., 2004. Gender differences in the perceived risk of buying online and the effects of receiving a site recommendation. J. Bus. Res. 57 (7), 768-775. https://doi.org/10.1016/S0148-2963(02)00363-6.

Hamilton, R., Price, L.L., 2019. Consumer journeys: developing consumer-based strategy. J. Acad. Market. Sci. 47, 187-191. https://doi.org/10.1007/s11747-019-00636-y.

Harris, J.L., Bargh, J.A., Brownell, K.D., 2009. 'Priming effects of television food advertising on eating behavior'. Health Psychol. 28 (4), 404-413. https://doi.org/ $10.1037 / \mathrm{a} 0014399$.

Hasan, B., 2010. Exploring gender differences in online shopping attitude. Comput. Hum. Behav. 26 (4), 597-601. https://doi.org/10.1016/j.chb.2009.12.012.

Hou, J., Elliott, K., 2010. Profiling online bidders. J. Market. Theor. Pract. 18 (2), 109-126. https://doi.org/10.2753/MTP1069-6679180201.

Hou, J., Elliott, K., 2016. Gender differences in online auctions. Electron. Commer. Res. Appl. 17 (3), 123-133. https://doi.org/10.1016/j.elerap.2016.04.004.

Hoyle, R.H., Panter, A.T., 1995. 'Writing about structural equation models'. In: Hoyle, R. H. (Ed.), Structural Equation Modelling: Concepts, Issues, and Applications. Sage Publications, Thousand Oaks, CA, pp. 158-176.

Hu, L., Bentler, P., 1999. Cutoff criteria for fit indexes in covariance structure analysis: conventional criteria versus new alternatives. Struct. Equ. Model. 6 (1), 1-55. https://doi.org/10.1080/10705519909540118.

Hu, L.-T., Bentler, P.M., 1999. Cutoff criteria for fit indexes in covariance structure analysis: conventional criteria versus new alternatives. Struct. Equ. Model. 6 (1), 1-55. https://doi.org/10.1080/10705519909540118.

Huang, J.-H., Yang, Y.-C., 2010. The relationship between personality traits and online shopping motivations. SBP (Soc. Behav. Pers.): Int. J. 38 (5), 673-680. https://doi. org/10.2224/sbp.2010.38.5.673.

Huang, Y.C., Wu, Y.C., Wang, Y.C., Boulanger, N.C., 2011. Decision making in online auctions. Manag. Decis. 49 (5), 784-800. https://doi.org/10.1108/ 00251741111130850.

Hughes, T., Stone, M., Aravopoulou, E., Tiu Wright, L., Machtynger, L., 2018. Academic research into marketing: many publications, but little impact? Cogent Bus. \& Manag. 5 (1), 1-18. https://doi.org/10.1080/23311975.2018.1516108.

Ipsos, 2013. 'Socialogue: money talks'. Available at: http://www.ipsos-na.com/news -polls/pressrelease.aspx?id=6001. Accessed: 9 April 2018.

Isaac, A., 2016. How to market to millennials. The Telegraph 28 (July).

Kautonen, T., van Gelderen, M., Tornikoski, E.T., 2013. Predicting entrepreneurial behaviour: a test of the theory of planned behaviour. Appl. Econ. 45 (6), 697-707. https://doi.org/10.1080/00036846.2011.610750.

Kautonen, T., van Gelderen, M., Fink, M., 2015. Robustness of the Theory of Planned Behavior in predicting entrepreneurial intentions and actions. Enterpren. Theor. Pract. 39 (3), 655-674. Available at: https://ssrn.com/abstract=2297281. Accessed: 5 October 2018.

Kim, D., Lehto, X.Y., Morrison, A.M., 2007. Gender differences in online travel information search: implications for marketing communications on the internet. Tourism Manag. 28 (2), 423-433. https://doi.org/10.1016/j.tourman.2006.04.001.

Kline, P., 2000. Handbook of Psychological Testing. Routledge, London.

Kline, R.B., 2016. Principles and Practice of Structural Equation Modeling, second ed. The Guilford Press, New York, NY.

Korgaonkar, P., Petrescu, M., Becerra, E., 2014. Shopping orientations and patronage preferences for internet auctions. Int. J. Retail Distrib. Manag. 42 (5), 352-368. https://doi.org/10.1108/IJRDM-03-2012-0022.

Lai, M., Wu, W.Y., Lin, S.M., 2008. A qualitative approach for conceptualizing consumer decision-making in online auctions. In: Lee, A.Y., Soman, D. (Eds.), Advances in Consumer Research, vol. 35, pp. 319-324. Association for Consumer Research, Duluth, MN. Available at: http://www.acrwebsite.org/. Accessed: 2 December 2017.

Lee, M.C., 2009. Factors influencing the adoption of internet banking: an integration of TAM and TPB with perceived risk and perceived benefit. Electron. Commer. Res. Appl. 8 (3), 130-141. https://doi.org/10.1016/j.elerap.2008.11.006.

Leisen Pollack, B., Alexandrov, A., 2013. Nomological validity of the net promoter Index question. J. Serv. Market. 27 (2), 118-129. https://doi.org/10.1108/ 08876041311309243.

Leonard, L.N.K., 2012. Attitude influencers in C2C e-commerce: buying and selling. J. Comput. Inf. Syst. 52 (3), 11-17. https://doi.org/10.1080/ 08874417.2012.11645554.

Li, R., Chung, T.-L., Fiore, A.M., 2017. 'Factors affecting current users' attitude towards e-auctions in China: an extended TAM study'. J. Retailing Consum. Serv. 34 (1), 19-29. https://doi.org/10.1016/j.jretconser.2016.09.003.

Lian, J.-W., Yen, D.C., 2014. Online shopping drivers and barriers for older adults: age and gender differences. Comput. Hum. Behav. 37 (8), 133-143. https://doi.org/ 10.1016/j.chb.2014.04.028.

Liao, S., Shao, Y.P., Wang, H., Chen, A., 1999. The adoption of virtual banking: an empirical study. Int. J. Inf. Manag. 19 (1), 63-74. https://doi.org/10.1016/S02684012(98)00047-4.

Lu, Y., Cao, Y., Wang, B., Yang, S., 2011. 'A study on factors that affect users' behavioural intention to transfer usage from the offline to the online channel'. Comput. Hum. Behav. 27 (1), 411-421. https://doi.org/10.1016/j.chb.2010.08.013.

Lyons, K., 2016. Generation Y: a Guide to a Much-Maligned Demographic, vol. 7. The Guardian (March).

Majadi, N., Trevathan, J., Gray, H., 2018. A run-time algorithm for detecting shill bidding in online auctions. J. Ther. Appl. Electron. Comm. Res. 13 (3), 17-49. https://doi.org/10.4067/S0718-18762018000300103.

McLaughlin, C., Bradley, L., Prentice, G., Verner, E.-J., Loane, S., 2017. Consumer to consumer (C2C) online auction transaction intentions: an application of the Theory of Planned Behaviour. DBS Bus. Rev. J. 1 (1), 5-25. https://doi.org/10.22375/dbsbr. v1.4. 
Meyers-Levy, J., Loken, B., 2015. Revisiting gender differences: what we know and what lies ahead. J. Consum. Psychol. 25 (1), 129-149. https://doi.org/10.1016/j. jcps.2014.06.003.

Miles, J.N.V., Shevlin, M., 2007. 'A time and a place for incremental fit indices'. Pers. Indiv. Differ. 42 (5), 869-874. https://doi.org/10.1016/j.paid.2006.09.022.

Mohamed, N., Hussein, R., Zamzuri, N.H.A., Haghshenas, H., 2014. 'Insights into individuals' online shopping continuance intention'. Ind. Manag. Data Syst. 114 (9), 1453-1476. https://doi.org/10.1108/IMDS-07-2014-0201.

Morgan, R.M., Hunt, S.D., 1994. 'The commitment-trust theory of relationship marketing'. J. Market. 58 (3), 20-38. https://doi.org/10.2307/1252308.

Nadeem, W., Andreini, D., Salo, J., Laukkanen, T., 2015. 'Engaging consumers online through websites and social media: a gender study of Italian Generation Y clothing consumers'. Int. J. Inf. Manag. 35 (4), 432-442. https://doi.org/10.1016/j. ijinfomgt.2015.04.008.

Nirmala, R.P., Dewi, I.J., 2011. The effects of shopping orientations, consumer innovativeness, purchase experience, and gender on intention to shop for fashion products online. Gadjah Mada Int. J. Bus. 13 (1), 65-83. https://doi.org/10.22146/ gamaijb.5495.

Noble, S.M., Haytko, D.L., Phillips, J., 2009. What drives college-age Generation Y consumers? J. Bus. Res. 62 (6), 617-628. https://doi.org/10.1016/j. jbusres.2008.01.020.

Ow, T.T., Spaid, B.I., Wood, C.A., Ba, S., 2018. Trust and experience in online auctions. J. Organ. Comput. Electron. Commer. 28 (4), 294-314. https://doi.org/10.1080/ 10919392.2018.1517478.

Pahnila, S., Siponen, M., Zheng, X., 2011. Integrating habit into UTAUT: the Chinese eBay case. Pac. Asia J. Assoc. Inf. Syst. 3 (2), 1-30. https://doi.org/10.17705/ 1 pais.03201.

Parment, A., 2013. Generation Y vs Baby Boomers: shopping behavior, buyer involvement and implications for retailing. J. Retailing Consum. Serv. 20 (2), 189-199. https://doi.org/10.1016/j.retconser.2012.12.001.

Parsons, A.G., 2002. Non-functional motives for online shoppers: why we click. J. Consum. Market. 19 (5), 380-392. https://doi.org/10.1108/ 07363760210437614.

Pavlou, P.A., Fygenson, M., 2006. Understanding and predicting electronic commerce adoption: an extension of the Theory of Planned Behavior. Manag. Inf. Syst. Quart. 30 (1), 115-143. Available at: Business Source Complete, EBSCOhost [Online] (Accessed: 25 January 2019).

Pavlou, P.A., Gefen, D., 2005. Psychological contract violation in online marketplaces: antecedents, consequences, and moderating role. Inf. Syst. Res. 16 (4), 372-399. https://doi.org/10.1287/isre.1050.0065.

Peighambari, K., Sattari, S., Kordestani, A., Oghazi, P., 2016. Consumer Behavior Research: A Synthesis of the Recent Literature, vol. 6. SAGE Open, pp. 1-9. https:// doi.org/10.1177/2158244016645638, 2.

Pinker, E.J., Seidmann, A., Vakrat, Y., 2003. Managing online auctions: current business and research issues. Manag. Sci. 49 (11), 1457-1484. https://doi.org/10.1287/ mnsc. 49.11.1457.20584.

Pinker, E.J., Seidmann, A., Vakrat, Y., 2010. Using bid data for the management of sequential, multi-unit, online auctions with uniformly distributed bidder valuations. Eur. J. Oper. Res. 202 (2), 574-583. https://doi.org/10.1016/j.ejor.2009.05.029.

Prensky, M., 2001. Digital natives, digital immigrants. Horizon 9 (5), 1-6. https://doi. org/10.1108/10748120110424816.

Ramayah, T., Ignatius, J., 2005. Impact of perceived usefulness, perceived ease of use and perceived enjoyment on intention to shop online. IFCAI J. Manag. 3 (3), 36-51. Available at: https://www.semanticscholar.org/. Accessed: 6 March 2018.

Rauniar, R., Rawski, G., Crumbly, G., Simms, J., 2009. 'C2C online auction website performance: buyer's perspective'. J. Electron. Res. 10 (2), 56-75. Available at: http ://www.csulb.edu/journals/jecr/issues/20092/paper1.pdf. Accessed: 20 July 2019).

Riedl, R., Hubert, M., Kenning, P., 2010. Are there neural gender differences in online trust? An empathizing-systemizing-theory-based fMRI study on the perceived trustworthiness of eBay offers. MIS Q. 34 (2), 397-428. https://doi.org/10.2307/ 20721434.

Rodgers, S., Harris, M.A., 2003. 'Gender and e-commerce: an exploratory study'. J. Advert. Res. 43 (3), 322-329. https://doi.org/10.2501/JAR-43-3-322-329.

Roggio, A., 2012. 'Getting started with eBay', practical ecommerce. Available at: http://www.practicalecommerce.com/Getting-Started-with-eBay. Accessed: 14 March 2018.

Rohm, A.J., Swaminathan, V., 2004. A typology of online shoppers based on shopping motivations. J. Bus. Res. 57 (7), 748-757.

Ruane, L., Wallace, E., 2013. Generation Y females online: insights from brand narratives. Qual. Mark. Res. Int. J. 16 (3), 315-335. https://doi.org/10.1108/ 13522751311326125.
Sanayei, A., Bahmani, E., 2012. 'Integrating TAM and TPB with perceived risk to measure customers' acceptance of internet banking'. Int. J. Integrated Supply Manag. 10 (1), 25-37. Available at: https://ijism.ricest.ac.ir/. Accessed: 2 June 2017.

Sangran, S., Siguaw, J.A., Guan, C., 2009. A comparative study of motivation differences for online shopping. The DATA BASE Adv. Inf. Syst. 40 (4), 28-42. https://doi.org/ 10.1145/1644953.1644957.

Saputra, R.S., Warokka, A., Naruephai, N., 2012. 'The key drivers of online consumers' intention to purchase in an online auction: a reference from southeast emerging market'. J. Internet e Bus. Stud. 1 (1), 1-17. Available at: http://ibimapublishing.co m/articles/JIEBS/2012/278071/. Accessed: 17 March 2019.

Schlaegel, C., 2015. 'Understanding individuals' initial and continued use of online auction marketplaces: a meta-analysis'. Manag. Res. Rev. 38 (8), 855-907. https:// doi.org/10.1108/MRR-09-2013-0210.

Schreiber, J.B., Nora, A., Stage, F.S., Barlow, E.A., King, J., 2006. Reporting structural equation modeling and confirmatory factor Analysis results: a review. J. Educ. Res. 99 (6), 323-338. https://doi.org/10.3200/JOE.R.99.6.323-338.

Selwyn, N., 2009. The digital native: myth and reality. ASLIB Proc.: New Inform. Persp. 61 (4), 364-379. https://doi.org/10.1108/00012530910973776.

Seybold, P.B., 2001. Get inside the lives of your customers. Harv. Bus. Rev. 79 (5), 80-89.

Shareef, M.A., Archer, A., Fong, W., Rahman, M.O., Mann, I.J., 2013. Online buying behaviour and perceived trustworthiness. Br. J. Appl. Sci. Technol. 3 (4), 662-683. Available at: http://www.journalrepository.org/. Accessed: 16 August 2017.

Shehryar, O., 2008. 'The effect of buyers' gender, risk-proneness, and time remaining in an internet auction on the decision to bid or buy-it-now'. J. Prod. Brand Manag. 17 (5), 356-365. https://doi.org/10.1108/10610420810896112.

Stafford, T.F., Turan, A., Raisinghani, M.S., 2004. International and cross-cultural influences on online shopping behavior. J. Global Inf. Technol. Manag. 7 (2), $70-87$. https://doi.org/10.1080/1097198X.2004.10856373.

Steiger, J.H., 1990. Structural model evaluation and modification: an interval estimation approach. Multivariate Behav. Res. 25 (2), 173-180. https://doi.org/10.1207/ s15327906mbr2502_4.

Swaminathan, V., Lepkowska-White, E., Rao, B.P., 1999. Browsers or buyers in cyberspace? An investigation of factors influencing electronic exchange. J. Computer-Mediated Commun. 5 (2) https://doi.org/10.1111/j.1083-6101.1999. tb00335.x.

Terry, D.J., O'Leary, J.E., 1995. The Theory of Planned Behaviour: the effects of perceived behavioural control and self-efficacy. Br. J. Soc. Psychol. 34 (2), 199-220. https://doi.org/10.1111/j.2044-8309.1995.tb01058.x.

Verhagen, T., Dolen, W.V., 2011. The influence of online store beliefs on consumer online impulse buying: a model and empirical application. Inf. Manag. 48 (8), 320-327. https://doi.org/10.1016/j.im.2011.08.001.

Vicente, M.R., 2015. Determinants of C2C e-commerce: an empirical analysis of the use of online auctions websites among Europeans. Appl. Econ. Lett. 22 (12), 978-981. https://doi.org/10.1080/13504851.2014.993127.

Wallop, H., 2014. 'Gen Z, Gen Y, baby boomers - a guide to the generations'. The Telegraph 31 (July).

Wang, C., Zhang, P., 2012. The evolution of social commerce: the people, management, technology, and information dimensions. Commun. Assoc. Inf. Syst. 31 (5), 105-127. https://doi.org/10.17705/1CAIS.03105.

Weinberg, B.D., Davis, L., 2005. Exploring the WOW in online-auction feedback. J. Bus. Res. 58 (11), 1609-1621. https://doi.org/10.1016/j.jbusres.2004.06.004.

Wells, V.K., 2014. Behavioural psychology, marketing and consumer behaviour: a literature review and future research agenda. J. Market. Manag. 30 (11-12), 1119-1158. https://doi.org/10.1080/0267257X.2014.929161.

Wire, Business, 2018. Global online auction market 2018-2022, ease of bidding to boost growth, technavio. Available at: https://www.businesswire.com/. Accessed: 10 January 2019.

Yeh, J.-C., Hsiao, K.-L., Yang, W.-N., 2012. 'A study of purchasing behavior in Taiwan's online auction websites: effects of uncertainty and gender differences'. Internet Res. 22 (1), 98-115. https://doi.org/10.1108/10662241211199988.

Yen, C.-H., Lu, H.-P., 2008. Factors influencing online auction repurchase intention. Internet Res. 18 (1), 7-25. https://doi.org/10.1108/10662240810849568.

Yousafzai, S.Y., Foxall, G.R., Pallister, J.G., 2010. Explaining internet banking behavior: theory of reasoned action, theory of planned behavior, or technology acceptance model? J. Appl. Soc. Psychol. 40 (5), 1172-1202. https://doi.org/10.1111/j.15591816.2010.00615.x.

Zhou, L., Dai, L., Zhang, D., 2007. Online shopping acceptance model: a critical survey of consumer factors in online shopping. J. Electron. Commer. Res. 8 (1), 41-62. Available at: http://www.jecr.org/. Accessed: 05 November 2017.

Zhou, Z., Jin, X., Fang, Y., 2014. Moderating role of gender in the relationships between perceived benefits and satisfaction in social virtual world continuance. Decis. Support Syst. 65, 69-79. https://doi.org/10.1016/j.dss.2014/05.004.

Zinkhan, G.M., 1992. Human nature and models of consumer decision making. J. Advert. 21 (4). II-III. Available at: www.jstor.org/stable/4188852. Accessed: 02 March 2020. 